\title{
Treatment of cyclic vomiting syndrome with co- enzyme Q10 and amitriptyline, a retrospective study
}

Richard G Boles ${ }^{1,2 *}$, Mary R Lovett-Barr ${ }^{3}$, Amy Preston ${ }^{3}$, B UK Li ${ }^{4}$, Kathleen Adams ${ }^{3}$

\begin{abstract}
Background: Cyclic vomiting syndrome (CVS), which is defined by recurrent stereotypical episodes of nausea and vomiting, is a relatively-common disabling condition that is associated with migraine headache and mitochondrial dysfunction. Co-enzyme Q10 (Co-Q) is a nutritional supplement that has demonstrated efficacy in pediatric and adult migraine. It is increasingly used in CVS despite the complete lack of studies to demonstrate its value in treatment

Methods: Using an Internet-based survey filled out by subjects with CVS or their parents, the efficacy, tolerability and subject satisfaction in CVS prophylaxis were queried. Subjects taking Co-Q (22 subjects) were compared against those taking amitriptyline (162 subjects), which is the general standard-of-care.

Results: Subjects/parents reported similar levels of efficacy for a variety of episode parameters (frequency, duration, number of emesis, nausea severity). There was a $50 \%$ reduction in at least one of those four parameters in $72 \%$ of subjects treated with amitriptyline and $68 \%$ of subjects treated Co-Q. However, while no side effects were reported on Co-Q, $50 \%$ of subjects on amitriptyline reported side effects $\left(P=5 \times 10^{-7}\right)$, resulting in $21 \%$ discontinuing treatment $(P=0.007)$. Subjects/parents considered the benefits to outweigh the risks of treatment in $47 \%$ of cases on amitriptyline and $77 \%$ of cases on Co-Q ( $P=0.008)$.
\end{abstract}

Conclusion: Our data suggest that the natural food supplement Co-Q is potentially efficacious and tolerable in the treatment of CVS, and should be considered as an option in CVS prophylaxis. Our data would likely be helpful in the design of a double-blind clinical trial.

\section{Background}

Cyclic vomiting syndrome (CVS) is defined as recurrent identical episodes of nausea and vomiting, with the absence of these symptoms between episodes [1]. Prior to the advent of successful therapy, CVS was in most cases a disabling condition. Episodes of nausea and vomiting are generally severe and often require intravenous fluid therapy for dehydration. Frequent and prolonged school or work absences lead to academic or work disability. CVS is apparently common, being present in about 2\% of Scottish [2] and Western Australian [3] school children.

\footnotetext{
* Correspondence: rboles@chla.usc.edu

'Division of Medical Genetics and the Saban Research Institute, Childrens Hospital Los Angeles, 4650 Sunset Blvd., Los Angeles, California, 90027 USA
}

CVS is generally believed to be a variant of migraine based on overlapping symptoms such as headache, nausea, and photophobia. There is also frequent progression of CVS to migraine headache, and a very high prevalence of migraine among close relatives of CVS patients [4]. Furthermore, CVS and migraine respond to many of the same medications including amitriptyline, cyproheptadine, propranolol and triptans. Amitriptyline (Elavil ${ }^{\circ}$ ), a tricyclic "antidepressant" is the most widely prescribed prophylactic medication used for the treatment of CVS. Response rates vary from $52-73 \%$ in open-label $[5,6]$ and subject recall-based $[4,7]$ studies in children and adults. In a recent consensus statement on management, amitriptyline was recommended as the first-line treatment choice for CVS prophylaxis in patients age 5 years and older [1].

\section{() BiolMed Central}


Recently, the use of co-enzyme Q10 (Co-Q), also known as ubiquinone, has been gaining in popularity among CVS patient groups. Co-Q is a commonly-used dietary supplement that is widely available in retail settings. Co-Q is a naturally-occurring steroid-derived hydrophobic compound that is present in all organisms and essentially all food sources. Co-Q serves as the electron shuttle between complexes 1 or 2 and complex 3 of the mitochondrial respiratory chain [8]. It is thus essential for energy metabolism. Humans can manufacture this compound but often do so in inadequate quantities, with the remainder obtained from the diet. Physicians and other health care providers are increasingly recommending Co-Q for the treatment of a wide variety of conditions, including migraine [9], heart failure [10], statin treatment [11], neurodegenerative conditions [12], and primary inborn errors of mitochondrial energy metabolism [13].

Mitochondrial dysfunction is hypothesized to be a factor in the pathogenesis of both CVS and migraine headache based upon studies utilizing ${ }^{31} \mathrm{P}$-MRS [14] in migraine, and in both conditions by decreased respiratory complex enzymology [15-17], disease-associated mitochondrial DNA (mtDNA) sequence variants [18-23], and preferential maternal inheritance [4,24-27]. mtDNA is exclusively inherited from the mother. Three reasons prompted us to study whether Co-Q has efficacy in CVS prophylaxis: 1) demonstrated efficacy of Co-Q in migraine prophylaxis; 2 ) its increasingly popular usage in CVS; and 3) the association of both conditions with mitochondrial dysfunction.

In this retrospective study, we compare the efficacy, tolerability and patient satisfaction of $\mathrm{Co}-\mathrm{Q}$ with the current standard-of-care in CVS therapy: amitriptyline.

\section{Methods}

The study was advertised by the Cyclic Vomiting Syndrome Association (CVSA), a patient/family and professional led organization over a one-year period. Recruitment was conducted by means of newsletters, the CVSA website, e-mails to members and associated physicians, and by word of mouth. Individuals given a diagnosis of CVS by a health care professional, as attested to by the subject/parent by survey, were invited to participate in this study by completing an approximately 30-minute Internet-based survey (Survey Monkey). There was the option of completing the identical survey on paper. Subjects remained anonymous, and all aspects of this study were approved by the Childrens Hospital Los Angeles Institutional Review Board.

Efficacy was queried in terms of four different vomiting episode-based parameters: episode frequency, episode duration, number of emeses, and nausea severity. A reduction of at least $50 \%$ in each parameter was scored as positive and any lesser response as negative. The compound measure of "episode improvement" was scored as positive if at least one of the above four parameters were scored as positive. The data was reviewed in terms of efficacy and tolerability on low $(<0.5 \mathrm{mg} / \mathrm{kg} /$ day), medium, and high $(\geq 1.0 \mathrm{mg} / \mathrm{kg} /$ day $)$ dosage amitriptyline, and for low and high $(\geq 10 \mathrm{mg} / \mathrm{kg} /$ day or $\geq$ $300 \mathrm{mg}$ in a patient $\geq 30 \mathrm{~kg}$ ) dosage Co-Q. The data were also reviewed in terms of the child ( $<12$ years), adolescent and adult ( $\geq 18$ years) onset of stereotypical vomiting episodes. However, there were insufficient numbers of adolescent-onset subjects in order to fully characterize this group, and thus child- and adolescentonset data were combined in order to create a "pediatric-onset" group. Chi square or Fisher exact tests were used as appropriate. Statistics were performed by WinSTAT Statistics for Windows, Kalmia Co. Inc., Cambridge, MA, and by custom-made software.

\section{Results}

A total of 385 subjects completed the survey, of which 18 were excluded for the absence of a health professional-assigned diagnosis, and 13 for failure to meet both the Rome III [28] and NASPGHAN [1] diagnostic criteria for CVS based upon survey responses. Among the 347 subjects remaining, 277 and 82 reported experience with amitriptyline and with $\mathrm{Co}-\mathrm{Q}$, respectively. The final tally was 249 subjects for amitriptyline and 32 subjects for Co-Q after subtraction of 22 subjects who had started on both compounds at the same time, and 63 subjects that had started on Co-Q and/or amitriptyline and L-carnitine together. In both groups, 14 subjects were tried on both therapies at different times, and data on both are recorded.

Subjects reported treatment with a variety of different dosages of amitriptyline and Co- $\mathrm{Q}$, yet no dose-response relationship or trend was evident. Furthermore, no relationship or trends were noted in regards to the age of onset of vomiting episodes with either therapy. One potential exception was a possible trend in a reduction of episode frequency by $\mathrm{Co}-\mathrm{Q}$ in pediatric-onset $(<18$ years; $10 / 17$ ) but not in adult-onset (1/5) CVS ( $\mathrm{P}=$ $0.15)$. Thus, data for all dosages and ages were combined for statistical analyses.

In the compound measure of episode improvement, there was no difference reported between the therapies, with amitriptyline scoring positive in $72 \%$ and Co-Q in $68 \%$ (odds ratio $=1.2,95 \%$ confidence interval 0.5-3.0). Furthermore, similar rates of response with both therapies were noted with all four episode parameters (Table 1).

Side effects were frequently reported with amitriptyline $(50 \%)$, and not recorded with Co-Q $\left(P=5 \times 10^{-7}\right)$ (Table 1). Among all subjects treated with amitriptyline, 
Table 1 Efficacy, tolerability and patient satisfaction of co-enzyme Q10 and amitriptyline in the treatment of cyclic vomiting syndrome

\begin{tabular}{|c|c|c|c|c|c|c|}
\hline & Amitriptyline & & & Co-enzyme Q10 & & \\
\hline & $\begin{array}{l}\text { Pediatric Onset }{ }^{1} \\
<18 \text { y }\end{array}$ & $\begin{array}{l}\text { Adult Onset } \geq 18 \\
y\end{array}$ & $\begin{array}{l}\text { All } \\
\text { Subjects }\end{array}$ & $\begin{array}{l}\text { Pediatric Onset }{ }^{1} \\
<18 \text { y }\end{array}$ & $\begin{array}{l}\text { Adult Onset } \geq 18 \\
y\end{array}$ & $\begin{array}{l}\text { All } \\
\text { Subjects }\end{array}$ \\
\hline \multirow[t]{2}{*}{ Episode Frequency $^{2}$} & $62 / 113$ & $26 / 49$ & $88 / 162$ & $10 / 17$ & $1 / 5$ & $11 / 22$ \\
\hline & $55 \%$ & $53 \%$ & $54 \%$ & $59 \%$ & $20 \%$ & $50 \%$ \\
\hline \multirow[t]{2}{*}{ Episode Duration $^{2}$} & $59 / 112$ & $19 / 43$ & $78 / 155$ & $5 / 16$ & $3 / 6$ & $8 / 22$ \\
\hline & $53 \%$ & $44 \%$ & $50 \%$ & $31 \%$ & $50 \%$ & $36 \%$ \\
\hline \multirow[t]{2}{*}{ Number of Emesis ${ }^{2}$} & $52 / 110$ & $6 / 16$ & $70 / 154$ & $6 / 16$ & $2 / 4$ & $8 / 20$ \\
\hline & $47 \%$ & $41 \%$ & $45 \%$ & $38 \%$ & $50 \%$ & $40 \%$ \\
\hline \multirow[t]{2}{*}{ Nausea Severity $^{2}$} & $47 / 111$ & $21 / 46$ & $68 / 157$ & $7 / 18$ & $4 / 7$ & $11 / 25$ \\
\hline & $42 \%$ & $46 \%$ & $43 \%$ & $39 \%$ & $57 \%$ & $40 \%$ \\
\hline \multirow[t]{2}{*}{ Episode Improvement $^{3}$} & $88 / 123$ & $39 / 54$ & $127 / 177$ & $12 / 18$ & $5 / 7$ & $17 / 25$ \\
\hline & $72 \%$ & $72 \%$ & $72 \%$ & $67 \%$ & $71 \%$ & $68 \%$ \\
\hline \multirow[t]{2}{*}{ Side Effects Reported } & $72 / 139$ & $30 / 63$ & $102 / 202$ & $0 / 20$ & $0 / 8$ & $0 / 28$ \\
\hline & $52 \%$ & $48 \%$ & $50 \%$ & $0 \%$ & $0 \%$ & $0 \%$ \\
\hline \multirow{2}{*}{$\begin{array}{l}\text { Discontinued Therapy Due to Side } \\
\text { Effects }\end{array}$} & 29/137 & $13 / 61$ & $42 / 198$ & $0 / 20$ & $0 / 8$ & $0 / 28$ \\
\hline & $21 \%$ & $21 \%$ & $21 \%$ & $0 \%$ & $0 \%$ & $0 \%$ \\
\hline \multirow{2}{*}{$\begin{array}{l}\text { Subject Statement of Risks V. } \\
\text { Benefits }{ }^{4}\end{array}$} & $49 / 94$ & $14 / 40$ & $63 / 134$ & $13 / 16$ & $4 / 6$ & $17 / 22$ \\
\hline & $52 \%$ & $35 \%$ & $47 \%$ & $81 \%$ & $67 \%$ & $77 \%$ \\
\hline \multirow[t]{2}{*}{ Subjects' Recommendation ${ }^{5}$} & $65 / 103$ & $23 / 39$ & $88 / 142$ & $12 / 19$ & $4 / 6$ & $16 / 25$ \\
\hline & $63 \%$ & $59 \%$ & $62 \%$ & $63 \%$ & $67 \%$ & $64 \%$ \\
\hline \multirow{2}{*}{$\begin{array}{l}\text { Subject on Therapy at Time of } \\
\text { Survey }\end{array}$} & $68 / 111$ & $30 / 48$ & $98 / 159$ & $14 / 19$ & $6 / 7$ & $20 / 26$ \\
\hline & $61 \%$ & $63 \%$ & $62 \%$ & $74 \%$ & $86 \%$ & $77 \%$ \\
\hline
\end{tabular}

The number of adolescent-onset cases was small, so the data were combined with the child-onset data.

${ }^{2}$ Proportion reporting a $50 \%$ reduction in this parameter

${ }^{3}$ Proportion reporting a $50 \%$ reduction in at least one of the above four parameters

"'Do you believe that the improvement you receive of [inset treatment name], if any, justified the side effects that you experienced?" - proportion answering as "yes, strongly" or "yes", as opposed to "sort of equal/not sure", "no" or "no, strongly".

${ }^{5 " W o u l d ~ y o u ~ r e c o m m e n d ~[i n s e t ~ t r e a t m e n t ~ n a m e] ~ t o ~ a ~ f r i e n d ~ o r ~ r e l a t i v e ~ w i t h ~ C V S ? " ~-~ p r o p o r t i o n ~ a n s w e r i n g ~ a s ~ p e r ~}{ }^{4}$ above.

$21 \%$ discontinued $(42 / 198)$ the drug because of side effects. None of the 28 patients stopped Co-Q because of side effects $(\mathrm{P}=0.007)$. Queried as to whether the efficacy justified the side effects (Table 1), those taking Co-Q reported a significantly higher patient satisfaction than did those taking amitriptyline (77\% responding as positive vs. $47 \%, \mathrm{P}=0.008$, odds ratio $=3.6$, $95 \%$ confidence interval $=1.2-10)$. However, when asked if they would recommend the agent to a relative or friend, the difference vanishes (positive responses: amitriptyline $62 \%$, Co-Q 64\%). Overall, there was a potential trend that subjects were more likely to remain on Co-Q versus on amitriptyline at the time of the survey $(77 \% \mathrm{v} .62 \%$, odds ratio 2.0, 95\% confidence interval 0.75-5.2).

\section{Discussion}

CVS generally results in severe discomfort, dehydration and disability, and despite prophylactic therapy substantial numbers of patients continue to suffer from repeated vomiting episodes. Our result of $72 \%$ efficacy (defined by compound measure) in those taking prophylactic amitriptyline agrees with the 52 to $73 \%$ efficacy rates reported in four previous studies [4-7]. This result also supports the overall validity of our on-line survey methodology. Our data is also consistent with our own clinical experience, in that overall efficacy is good (72\%), yet side effects are frequent (50\%), and often result in discontinuation of treatment $(21 \%)$. Overall, approximately half $(47 \%)$ of 134 subjects taking amitriptyline reported that the benefits outweighed the side effects of treatment. Furthermore, our data regarding the preventative treatment of CVS with Co-Q is consistent with our clinical experience, in that overall efficacy is good (69\%), with side effects being rare $(0 / 22)$. Three-quarters (77\%) of subjects taking Co-Q reported that the benefits outweighed the side effects, a significantly higher portion than that with amitriptyline.

There are substantial child versus adult-related differences in clinical CVS, such as longer and more frequent episodes and more severe inter-episodic nausea 
among adults [29]. Furthermore, a strong association with the $16519 \mathrm{~T}$ and $3010 \mathrm{~A}$ mtDNA polymorphisms was noted in child-onset (< age 12 years), but not in adult-onset ( $\geq 18$ years) cases [30]. Although the numbers of subjects in some categories were small, overall efficacy rates for both amitriptyline (70\% v. $72 \%)$ and Co-Q $(71 \%$ v. $71 \%)$ were very similar among subjects with child ( $<12$ years) and adult ( $\geq 18$ years) onset, respectively. Thus, our data do not suggest that the choice of either treatment should differ between pediatric or adult patients.

The limitations of this study are the subjective nature of retrospective subject/parent-completed questionnaires, the lack of validation data for our questionnaire, the lack of a proof of a physician-confirmed diagnosis of CVS, the self-selection bias in Internet questionnaire studies, the relatively small number of subjects reporting treatment with Co-Q, and the wide range of treatment durations, dosages, and in the case of $\mathrm{Co}-\mathrm{Q}$, brands and preparations (gel capsules, liquids, tablets, etc.) utilized. Interestingly, both amitriptyline and Co-Q seem to affect different parameters in different people, including episode frequency, episode duration, number of emeses, and severity of nausea. Neither therapy appears to affect the prodrome (data not shown). This information is important in the design of future prospective clinical trials in that complex end points for efficacy are needed. The failure to find a dose-response is expected as only the highest dosage attempted was queried, and thus the high-dose group may contain treatment failures that are not recorded as failures on lower doses.

The authors' clinical practice for treatment of CVS with Co-Q is $10 \mathrm{mg} / \mathrm{kg} /$ day divided bid, up to $200 \mathrm{mg}$ bid (either in liquid or gel capsule formulation). It also includes obtaining a blood Co-Q level in the case of an inadequate response, and increasing the dose for blood levels less than $3 \mathrm{mg} / \mathrm{L}$. Additional mitochondrial-targeted dietary supplements have also been used to prevent CVS attacks including L-carnitine, which has demonstrated efficacy in CVS in one small openlabel study [31] (authors' practice: $100 \mathrm{mg} / \mathrm{kg} / \mathrm{day}$ divided BID, up to one gram BID or TID), and riboflavin, which has demonstrated efficacy in migraine headache [32] (authors' practice: 100-400 mg/day, or one "B100" tablet a day). Anecdotally, in the authors' practice while some CVS patients respond well to cofactor therapy alone, many patients require drug therapy (generally amitriptyline) in addition. While this combination may have synergy based on anecdotal observations, the numbers of subjects in the current study are inadequate to address this question. This is another question for a prospective clinical trial.

\section{Conclusions}

Our data suggest that the naturally-occurring food supplement Co-Q (ubiquinone) has potential therapeutic efficacy and excellent tolerability in the treatment of CVS. This data would likely be helpful in the design of a double-blind, prospective clinical trial, which is needed to definitively determine the appropriate role of $\mathrm{Co}-\mathrm{Q}$ in CVS therapy. However, given the suggestion of efficacy, excellent tolerability, high patient satisfaction, and relatively low out-of-pocket costs (adult dose costs \$15-20 U.S. per month from many discount stores), health care providers may want to consider it as an low-risk therapeutic option in this disabling condition.

\section{Acknowledgements}

We would like to thank the subjects/families, several volunteers from the Cyclic Vomiting Syndrome Association (CVSA) who put in many hours of logistical support, and the physicians who recommended this study to their patients. Funding for logistical assistance such as recruitment letters and publication costs was provided by the CVSA.

\section{Author details}

'Division of Medical Genetics and the Saban Research Institute, Childrens Hospital Los Angeles, 4650 Sunset Blvd., Los Angeles, California, 90027 USA. ${ }^{2}$ Department of Pediatrics, Keck School of Medicine at the University of Southern California, 4650 Sunset Blvd., Los Angeles, California, 90027 USA. ${ }^{3}$ Cyclic Vomiting Syndrome Association, 2819 W. Highland Blvd., Milwaukee, Wisconsin, 53208 USA. ${ }^{4}$ Division of Pediatric Gastroenterology, Medical College of Wisconsin, 9000 West Wisconsin Avenue, Milwaukee, Wisconsin 53226 USA.

\section{Authors' contributions}

RGB conceived of the study, drafted the manuscript, and assisted in data analysis. MRLB performed most of the data analysis. All authors participated in designing the study (including the survey), recruiting subjects and physicians, and editing the manuscript.

\section{Competing interests}

The authors declare that they have no competing interests.

Received: 16 July 2009

Accepted: 28 January 2010 Published: 28 January 2010

\section{References}

1. Li BUK, Lefevre F, Chelimsky GG, Boles RG, Nelson SP, Lewis DW, Linder SL, Issenman RM, Rudolph CD: NASPGHAN Consensus Statement on the Diagnosis and Management of CVS.J Pediatr Gastroenterol Nutr 2008, 47(3):379-393.

2. Abu-Arafeh I, Russell G: Cyclical vomiting syndrome in children: a population-based study. J Pediatr Gastroenterol Nutr 1995, 21(4):454-458.

3. Cullen K, Macdonald WB: The periodic syndrome. Its nature and prevalence. Med J Australia 1963, 50(2):167-172.

4. Li BUK, Murray RD, Heitlinger LA, Robbins JL, Hayes JR: Is cyclic vomiting syndrome related to migraine?. J Pediatr 1999, 134(5):567-572.

5. Anderson JM, Sugerman KS, Lockhart JR, Weinberg WA: Effective prophylactic therapy for cyclic vomiting syndrome in children using amitriptyline or cyproheptadine. Pediatrics 1997, 100(6):977-981.

6. Prakash C, Clouse R: Cyclic vomiting syndrome in adults: clinical features and response to tricyclic antidepressents. Am J Gastroenterol 1999, 94(10):2856-2860.

7. Boles RG, Powers AL, Adams K: Cyclic vomiting syndrome plus. J Child Neurol 2006, 21(3):182-188.

8. Shoffner JM, Wallace DC: Oxidative phosphorylation diseases. The metabolic and molecular bases of inherited disease New York: McGrawHillScriver CR, Beaudet AL, Sly WS, Valle D , 7 1995, 1535-629. 
9. Sándor PS, Di Clemente L, Coppola G, Saenger U, Fumal A, Magis D Seidel L, Agosti RM, Schoenen J: Efficacy of coenzyme Q10 in migraine prophylaxis: A randomized controlled trial. Neurology 2005, 64(4):713-715.

10. Belardinelli R, Muçaj A, Lacalaprice F, Solenghi M, Seddaiu G, Principi F, Tiano L, Littarru GP: Coenzyme Q10 and exercise training in chronic heart failure. Eur Heart J 2006, 27(22):2675-2681.

11. Berthold HK, Naini A, Di Mauro S, Hallikainen M, Gylling H, Krone W, GouniBerthold I: Effect of Ezetimibe and/or Simvastatin on Coenzyme Q10 Levels in Plasma: A Randomised Trial. Drug Saf 2006, 29(8):703-712.

12. Beal MF: Mitochondrial dysfunction and oxidative damage in Alzheimer's and Parkinson's diseases and coenzyme Q10 as a potential treatment. J Bioenerg Biomembr 2004, 36(4):381-386.

13. Wong L-JC, Boles RG: Mitochondrial DNA Analysis in Clinical Laboratory Diagnostics. Clin Chim Acta 2005, 354:1-20.

14. Montagna P, Cortelli P, Monari L, Pierangeli G, Parchi P, Lodi R, lotti S, Frassineti $C$, Zaniol $P$, Lugaresi $E$, et al: 31P-magnetic resonance spectroscopy in migraine without aura. Neurology 1994, 44(4):666-669.

15. Montagna P, Sacquegna T, Martinelli P, Cortelli P, Bresolin N, Moggio M, Baldrati A, Riva R, Lugaresi E: Mitochondrial abnormalities in migraine. Preliminary findings. Headache 1988, 28(7):477-480.

16. Sangiorgi S, Mochi M, Riva R, Cortelli P, Monari L, Pierangeli G, Montagna P: Abnormal platelet mitochondrial function in patients affected by migraine with and without aura. Cephalalgia 1994, 14(1):21-23.

17. Boles RG, Williams JC: Mitochondrial Disease and Cyclic Vomiting Syndrome. Dig Dis Sci 1999, 44(Suppl):103S-107S.

18. Majamaa K, Finnilä, Turkka J, Hassinen IE: Mitochondrial DNA haplotype U as a risk factor for occipital stroke in migraine. Lancet 1998 352(9126):455-456.

19. Shimomura T, Kitano A, Marukawa H, Takahashi K: Mutation in platelet mitochondrial gene in patients with migraine. Cephalalgia 1995, 15(Suppl 13): 10 .

20. Boles RG, Chun N, Senadheera D, Wong L-JC: Cyclic vomiting syndrome and mitochondrial DNA mutations. Lancet 1997, 350(9087):1299-300.

21. Ojaimi J, Katsabanis S, Bower S, Quigley A, Byrne E: Mitochondrial DNA in stroke and migraine with aura. Cerebrovasc Dis 1998, 8(2):102-106.

22. Wang Q, Ito M, Adams K, Li BU, Klopstock T, Maslim A, Higashimoto T, Herzog J, Boles RG: Mitochondrial DNA control region sequence variation in migraine headache and cyclic vomiting syndrome. Am J Med Gene At 2004, 131(1):50-58.

23. Zaki EA, Freilinger T, Klopstock T, Baldwin EE, Heisner K, Adams K, Dichgans M, Wagler S, Boles RG: Two Common Mitochondrial DNA Polymorphisms Are Highly Associated With Migraine Headache and Cyclic Vomiting Syndrome. Cephalalgia 2009, 29(7):719-728.

24. Couch JR, Bearss C, Verhulst S: Importance of maternal heredity in the etiology of migraine. Neurology 1986, 36(Suppl 1):99.

25. Mortimer MJ, Kay J, Jaron A, Good PA: Does a history of maternal migraine or depression predispose children to headache and stomachache?. Headache 1992, 32(7):353-355.

26. Boles RG, Adams K, Ito M, Li BU: Maternal inheritance in cyclic vomiting syndrome with neuromuscular disease. Am J Med Genet 2003, 120A(4):474-482.

27. Boles RG, Adams K, Li BU: Maternal inheritance in cyclic vomiting syndrome. Am J Med Genet 2005, 133A(1):71-77.

28. Drossman DA, Corazziari E, Delvaux M, Spiller R, Talley NJ, Thompson WG, Whitehead WE: Rome III: The Functional Gastrointestinal Disorders McLean, VA: Degnon Associates, 32006.

29. Abell TL, Adams KA, Boles RG, Bousvaros A, Chong SK, Fleischer DR, Hasler WL, Hyman PE, Issenman RM, Li BU, Linder SL, Mayer EA, McCallum RW, Olden K, Parkman HP, Rudolph CD, Taché Y, Tarbell S, Vakil N: Cyclic vomiting syndrome in adults. Neurogastroenterol Motil 2008, 20(4):269-284

30. Boles RG, Zaki EA, Lavenbarg T, Hejazi R, Foran P, Freeborn J, Trilokekar S, McCallum R: Are pediatric and adult-onset cyclic vomiting syndrome (CVS) biologically different conditions? Relationship of adult-onset CVS with the migraine and pediatric CVS-associated common mtDNA polymorphisms 16519T and 3010A. Neurogastroenterol Motil 2009, 21(9):936-e72.

31. Van Calcar SC, Harding CO, Wolff JA: L-carnitine administration reduces number of episodes in cyclic vomiting syndrome. Clin Pediatr (Phila) 2002, 41(3):171-174.
32. Boehnke C, Reuter U, Flach U, Schuh-Hofer S, Einhäupl K, Arnold G: Highdose riboflavin treatment is efficacious in migraine prophylaxis: an open study in a tertiary care centre. Eur J Neurol 2004, 11(7):475-477.

\section{Pre-publication history}

The pre-publication history for this paper can be accessed here:http://www biomedcentral.com/1471-2377/10/10/prepub

doi:10.1186/1471-2377-10-10

Cite this article as: Boles et al:: Treatment of cyclic vomiting syndrome with co-enzyme Q10 and amitriptyline, a retrospective study. BMC Neurology 2010 10:10.

\section{Submit your next manuscript to BioMed Central and take full advantage of:}

- Convenient online submission

- Thorough peer review

- No space constraints or color figure charges

- Immediate publication on acceptance

- Inclusion in PubMed, CAS, Scopus and Google Scholar

- Research which is freely available for redistribution

Submit your manuscript at www.biomedcentral.com/submit
C Biomed Central 